\title{
MENINGKATKAN KEMAMPUAN BERPIKIR KREATIF MATEMATIS SISWA SMP MELALUI MODEL PEMBELAJARAN SEARCH, SOLVE, CREATE, AND SHARE DAN MODEL PROBLEM CENTERED LEARNING
}

\author{
Nia Marito Pakpahan ${ }^{1}$, Mangadar Simbolon ${ }^{2}$ \\ Program Studi Pendidikan Matematika \\ FKIP Universitas Advent Indonesia \\ 1niapahan@gmai.com, ${ }^{2}$ simbolonmangadar@gmail.com
}

\begin{abstract}
Abstrak: Kemampuan berpikir kreatif merupakan salah satu kemampuan matematis yang penting, namun dari hasil-hasil penelitian sebelumnya menunjukkan masih rendahnya kemampuan berpikir kreatif matematis siswa. Salah satu faktor penyebab rendahnya kemampuan berpikir kreatif matematis siswa oleh karena siswa yang kurang aktif dalam mengemukakan ide-ide secara kreatif dalam memecahkan masalah, mencetuskan gagasannya, serta memperinci permasalahan. Oleh karena itu diperlukan model pembelajaran yang dapat memacu keaktifan siswa dalam memecahkan masalah matematika. Penulis melakukan penelitian tentang penerapan model Search, Solve, Create and Share (SSCS) dan model Problem Centered Learning (PCL) guna membantu peningkatan kemampuan berpikir kreatif matematis siswa. Teknik pengumpulan data menggunakan instrumen tes untuk mengukur hasil belajar siswa. Adapun hasil dari penelitian ini menunjukkan bahwa: (1) kemampuan berpikir kreatif siswa yang menggunakan model Search, Solve, Create and Share (SSCS) berada pada kategori tinggi, sedangkan model PCL berada pada ketegori sedang, (2) terdapat perbedaan yang signifikan antara peningkatan kemampuan berpikir kreatif matematis antara siswa yang memperoleh model Search, Solve, Create and Share (SSCS) dan siswa yang memperoleh model PCL, dan (3) respon siswa terhadap model Search, Solve, Create and Share (SSCS) dan PCL masuk dalam kategori "suka".
\end{abstract}

Kata Kunci: Kemampuan berpikir kreatif, model pembelajaran Search, Solve, Create and Share, model Problem Centered Learning

Abstract: The ability of creative thinking is one of the important mathematical skills, but from the results of previous research indicates the low ability of students' mathematical creative thinking. One of the factors causing the low ability of students' mathematical creative thinking because students who are less active in expressing ideas creatively in solving problems, sparked his ideas, and detailed the problem. Therefore, it is needed a learning model that can accelerate students' activeness in solving math problems. The author conducted research on the application of Search, Solve, Create and Share (SSCS) model and Problem Centered Learning (PCL) model to help improve students' mathematical creative thinking ability. Data collection techniques use test instruments to measure student learning outcomes. The results of this study indicate that: (1) students' creative thinking ability using Search, Solve, Create and Share (SSCS) model is in high category, while PCL model is in moderate category, (2) there is a significant difference between improvement the ability of mathematical creative thinking between students who obtained the Search, Solve, Create and Share (SSCS) model and students who obtained the PCL model, and (3) the students' response to Search, Solve, Create and Share (SSCS) models and PCL entered into "like".

Keywords: Creative thinking ability, Search model, Solve, Create and Share, model of Problem Centered Learning 


\section{PENDAHULUAN}

Matematika merupakan mata pelajaran yang penting yang dapat membantu mempelajari ilmu lainnya, sehingga matematika dipelajari disemua jenjang pendidikan mulai dari taman kanak-kanak hingga perguruan tinggi. Matematika diharapkan dapat membentuk kemampuan peserta didik dalam menuangkan gagasan atau pengetahuan yang mereka miliki dengan melatih cara berpikir rasional, kritis dan berpikir kreatif (Susilo, 2015).

Menurut Kamus Besar Bahasa Indonesia (KBBI) berpikir adalah menggunakan akal budi untuk mempertimbangkan dan memutuskan sesuatu, sedangkan kreatif adalah memiliki daya cipta, memiliki kemampuan untuk menciptakan. Dengan demikian, berpikir kreatif adalah kemampuan untuk mempertimbangkan suatu daya cipta. Munandar (2009) menyatakan bahwa biasanya anak yang kreatif memiliki rasa ingin tahu yang besar, memiliki minat yang luas dan menyukai aktivitas yang kreatif, sehingga kreativitas yang dimiliki akan muncul sesuai dengan permasalahan yang sedang dihadapi siswa. Berpikir kreatif adalah salah satu kemampuan berpikir tingkat tinggi yang didasarkan atas kombinasi cara berpikir logis dan berpikir divergen yang mampu menghasilkan atau memproduksi ide-ide baru, pendekatan baru, perspektif baru maupun metode baru dalam menyelesaikan suatu masalah yang dikaitkan dengan kreativitas, sehingga berpikir kreatif sangat penting dalam kemampuan perkembangan potensi siswa.

Namun kenyaataan di lapangan bahwa kemampuan berpikir kreatif matematis siswa masih rendah, sebagaimana diungkapkan oleh Lestari (2016) mengatakan bahwa kreativitas siswa masih rendah yang dapat disebabkan oleh faktor pembelajaran yang selalu monoton sehingga dapat membuat siswa menjadi terasa jenuh saat belajar. Sehingga kemampuan berpikir kreatif matematis harus ditingkatkan. Sedangkan hasil penelitian Jellen dan Urban dalam Rachmawati dan Kurniati (2003) bahwa tingkat kreativitas siswa di Indonesia masih rendah.

Faktor penyebab rendahnya kemampuan berpikir kreatif matematis siswa di antaranya adalah: 1) siswa masih terbiasa dengan soal-soal rutin, sehingga ketika siswa diberikan soal yang sedikit menantang maka siswa tidak dapat mencari solusi dari masalah yang diberikan, 2) minimnya siswa yang aktif dalam mengemukakan ide-ide yang kreatif dalam memecahkan masalah, mencetuskan gagasannya, serta memperinci permasalahan. Untuk meningkatkan kemampuan berpikir kreatif matematis dapat dilakukan dengan memilih model pembelajaran yang dapat mendukung kemampuan tersebut. Adapun model pembelajaran yang ditawarkan dapat meningkatkan kemampuan berpikir kreatif siswa adalah model pembelajaran Search, Solve, Create and Share (SSCS) dan Problem Centered Learning (PCL). 
Prawindaswari, dkk (2015) model pembelajaran Search, Solve, Create and Share adalah model pembelajaran dengan empat fase, yaitu fase pertama search yang bertujuan untuk mengidentifikasi masalah, kedua fase solve yang bertujuan untuk merencanakan penyelesaian masalah, ketiga fase create yang bertujuan untuk melaksanakan penyelesaian masalah, dan fase yang keempat adalah fase share yang bertujuan untuk mensosialisasikan penyelesaian masalah yang kita lakukan.

Laporan Laboratory Network Program (Irwan, 2011), standar National Council of Teachers of Mathematics (NCTM) menyatakan bahwa hal yang dapat dicapai oleh model pembelajaran SSCS meliputi: 1) mengajukan soal/ masalah matematika; 2) membangun pengetahuan siswa; 3) mengembangkan keterampilan berpikir matematis dalam memecahkan permasalahan; 4) memberikan pertanyaan dan tugas-tugas yang menantang siswa; 5) mengembangkan pengetahuan siswa; 6) merangsang siswa untuk membuat ide-ide matematis; 7) berguna untuk perumusan masalah dan pemecahan masalah; dan 8) mengembangkan kemampuan siswa untuk memecahkan masalah. Dengan model pembelajaran Search, Solve, Create and Share maka peserta didik diharapkan untuk lebih aktif dalam belajar sehingga membuat siswa mampu menyelesaikan soal-soal non rutin dan menemukan ide-ide baru atau metode baru.

Selain model pembelajaran Search, Solve, Create and Share yang digunakan untuk meningkatkan kemampuan berpikir kreatif adalah model Problem Centered Learning. Problem Centered Learning merupakan model pembelajaran yang menekankan pembelajaran dalam memecahkan suatu masalah secara kreatif dan ilmiah sehingga soal-soalnya yang diberikan adalah soal-soal yang non rutin atau menantang. Siswa diberi keleluasan untuk mengeluarkan pendapatnya sendiri untuk memperoleh solusi berdasarkan pemikirannya. Hamzah (2015) aktivitas pembelajaran pada masalah-masalah yang menarik, siswa selalu berusaha untuk memecahkan suatu masalah secara mandiri terlebih dahulu dan ketika tidak bisa maka siswa akan berdiskusi dengan temannya maupun gurunya sehingga mampu bekerjasama dalam melakukan kegiatan pemecahan masalah.

Berdasarkan latar belakang yang telah dilampirkan di atas, maka penulis tertarik untuk melakukan penelitian dengan judul "Meningkatan Kemampuan Berpikir Kreatif Matematis Siswa SMP Melalui Model Pembelajaran Search, Solve, Create and Share (SSCS) dan Problem Centered Learning (PCL)."

Menurut Munandar (2009) menjelaskan bahwa kreativitas adalah kemampuan berdasarkan data atau informasi yang tersedia menemukan banyak kemungkinan jawaban terhadap suatu masalah, di mana penekanannya adalah kuantitas, ketepatgunaan dan 
keberagaman jawaban sehingga dengan adanya kreativitas yang dimiliki maka dapat meningkatkan prestasi dalam belajar. Ningrum dalam Nirmala (2016) menyatakan bahwa kemampuan berpikir matematika menjadi salah satu tolak ukur tercapainya tujuan matematika, terutama kemampuan berpikir tingkat tinggi, seperti kemampuan berpikir kreatif, logis, dan analitis untuk menemukan solusi dalam menyelesaikan masalah matematika dengan berbagai cara. Hikmah (2015) berpendapat bahwa kemampuan berpikir kreatif adalah kemampuan yang menciptakan sesuatu yang baru, baik berupa argument maupun solusi yang relatif berbeda dengan yang sebelumnya yang merupakan hasil dari penggabungan dua atau lebih konsep yang sudah ada.

Menurut Munandar (2009); Evans (Edistria, 2012) bahwa berpikir kreatif memiliki beberapa aspek:

1. Kepekaan (sensitivity) adalah kemampuan mengidentifikasi suatu masalah dalam konsep yang terkait atau strategi yang sesuai dalam menyelesaikan masalah itu.

2. Kelancaran/ kelenturan (fluency) adalah kemampuan dalam memunculkan argumen atau pertanyaan yang beragam, kemudian merencanakannya sebagai strategi yang digunakan dalam pemecahan masalah.

3. Keluwesan (flexibiity) adalah kemampuan siswa dalam menghasilkan ide-ide baru yang bervariasi dan berbeda dari yang sebelumnya.

4. Keaslian (originality) adalah kemampuan untuk menghasilkan cara yang tidak biasa dalam menyelesaikan masalah yang dikembangkan menjadi lebih lengkap.

5. Berpikir terperinci (elaboration) yaitu mampu mengembangkan, menambah, memperkaya suatu gagasan.

Berdasarkan uraian indikator tersebut, maka peneliti menggunakan indikator-indikator kemampuan berpikir kreatif matematis siswa sebagai berikut:

1. Kelancaran (Fluency)

Kelancaran adalah ketika seseorang mampu memikirkan cara menyelesaikan sebuah permasalahan dengan cepat dengan solusi lebih dari satu.

2. Kelenturan (Flexibility)

Kelenturan adalah ketika seseorang mampu menghasilkan lebih dari satu ide dalam menyelesaikan sebuah permasalahan.

3. Keaslian (Originality)

Keaslian adalah ketika seseorang mampu memberikan gagasan atau ide baru dan unik dalam sebuah permasalahan.

4. Keterincian (Elaboration) 
Keterincian adalah kemampuan seseorang untuk mengembangkan suatu gagasan menjadi lebih menarik.

Menurut Rahmi (2011) model Search, Solve, Create and Share (SSCS) adalah pembelajaran yang menggunakan pendekatan problem solving yang didesain untuk mengembangkan keterampilan berpikir sistematis, logis, teratur dan teliti. Model pembelajaran Search, Solve, Create and Share melibatkan siswa dalam menyelidiki sesuatu, membangkitkan minat bertanya serta memecahkan masalahmasalah nyata.

North Central Regional Education Laboratory (dalam Nurjannah, 2016) menjelaskan bahwa terdapat delapan standar dalam National Council of Teacher of Mathematic (NCTM) yang dapat dicapai oleh model pembelajaran Search, Solve, Create and Share yaitu:

1. Mengajukan soal/masalah matematika.

2. Membangun pengalaman dan pengetahuan siswa.

3. Mengembangkan kemampuan berpikir matematika yang meyakinkan siswa tentang keabsahan suatu keadaan, solusi, dugaan dan jawaban.

4. Menumbuhkan intelektual siswa : mengajukan pertanyaan dan tugastugas yang melibatkan siswa, dan menantang cara berpikir siswa.

5. Mengembangkan pengetahuan dan keterampilan matematika siswa.

6. Merangsang siswa untuk membuat koneksi dan mengembangkan kerangka kerja yang berhubungan dengan ide-ide matematika.

7. Menanamkan kemampuan perumusan masalah, pemecahan masalah, dan penalaran matematika.

8. Mengembangkan seluruh disposisi siswa untuk melakukan pekerjaan matematika.

Selanjutnya Pizzni,dkk. (Utami, 2011), model pembelajaran Search, Solve, Create and Share ini mengacu pada empat langkah penyelesaian masalah yang dimulai pada menyelidiki masalah (Search), merencanakan pemecahan masalah (Solve), mengkonstruksi pemecahan masalah (Create), dan terakhir adalah mengkomunikasikan penyelesaiannya yang diperolehnya (Share) sehingga membangkitkan minat bertanya siswa.

Problem Centered Learning (PCL) dalam bahasa Indonesia dapat diartikan dengan pembelajaran berpusat pada masalah. Hamzah (2015) menyatakan Problem Centered Learning merupakan pembelajaran matematika yang dapat membuat siswa aktif berpartisipasi dalam belajar dengan memberikan kesempatan kepada siswa untuk melakukan aktifitas yang potensial. Problem Centered Learning merupakan pembelajaran yang sangat potensial di mana permasalahannya diberikan untuk seluruh siswa di kelas tetapi diselesaikan dalam kolaboratif grup. 
Wheatley (Kurniawan, 2016) menyatakan bahwa dalam pembelajaran Problem Centered Learning terjadi 3 proses, yaitu:

1. Mengerjakan tugas

Pertama-tama guru menyiapkan kelas, kemudian menugaskan siswa untuk mengerjakan tugas. Guru memberikan tugas-tugas yang menantang kepada siswa untuk mengembangkan kemampuan matematisnya. Guru tidak memberikan prosedur kepada siswa dalam menyelesaikan persoalan tersebut sehingga siswa harus memahami dan mencoba untuk menyelesaikannya secara mendiri, karena siswa tidak diperbolehkan mendiskusikan solusi kepada temannya dan gurunya.

2. Kegiatan kelompok

Pada proses ini, guru mengkondisikan siswa untuk melanjutkan kegiatan kelompok. Guru membagi siswa menjadi beberapa kelompok kecil berdasarkan kemampuan siswa. Dalam kegiatan kelompok ini, setiap anggota harus berkolaborasi untuk meneukan pemecahan dari masalah dari hasil pemikiran mereka sendiri.

3. Berbagi (sharing)

Dalam kegiatan terakhir ini siswa disatukan kembali mejadi diskusi kelas. Setiap perwakilan dari anggota kelompok berbagi hasil diskusinya di depan kelas dan menjadi diskusi kelas dalam menemukan solusi yang berbeda. Peran guru pada proses ini hanyalah sebagai fasilitator dengan membantu diskusi kelas dan tidak bersifat menilai tetapi hanya bersifat mendorong.

\section{METODE PENELITIAN}

Penelitian ini merupakan penelitian kuantitatif yang bersifat komparatif atau membandingkan. Desain penelitian ditunjukkan pada Tabel 1.

Tabel 1. Desain Penelitian

\begin{tabular}{|c|c|c|}
\hline Kelompok & Variabel Bebas & Pengukuran \\
\hline $\mathrm{K}_{1}$ & $\mathrm{X}_{1}$ & $\mathrm{O}$ \\
\hline $\mathrm{K}_{2}$ & $\mathrm{X}_{2}$ & $\mathrm{O}$ \\
\hline
\end{tabular}

Keterangan:

$\mathrm{K}_{1} \quad$ : Kelompok 1

$\mathrm{K}_{2} \quad$ : Kelompok 2

$\mathrm{X}_{1} \quad$ : Model pembelajaran Seacrh, Solve, Create and Share (SSCS)

$\mathrm{X}_{2} \quad$ : Model Problem Centered Learning (PCL)

$\mathrm{O} \quad$ : Gain kemampuan berpikir kreatif matematis

Populasi dalam penelitian ini adalah siswa SMP di Kabupaten Bandung Barat. Penelitian dilakukan di SMPN 3 Lembang, Bandung Barat. Sampel yang digunakan dalam penelitian ini adalah kelas VIII F dan VIII G, di mana kelas VIII F akan memperoleh model Problem Centered Learning dan kelas VIII G akan memperoleh model pembelajaran Search, Solve, 
Create And Share. Jumlah sample yang digunakan dalam penelitian ini 34 siswa pada kelas VIII F dan 32 siswa pada kelas VIII G, sehingga jumlah sample yang digunakan dalam penelitian ini adalah 66 siswa. Variabel dalam penelitian ini adalah variabel bebas dan variabel terikat. Adapun variabel bebas dalam penelitian ini adalah model pembelajaran Search, Solve, Create and Share, dan model Problem Centered Learning. Variabel terikatnya adalah kemampuan berpikir kreatif matematis siswa.

Instrumen penelitian yang digunakan dalam penelitian ini adalah instrumen tes dan nontes. Instrumen tes terdiri dari pretest dan posttest, sedangkan insrtrumen non-tes berupa angket (sikap siswa tehadap model pembelajaran SSCS dan PCL, serta LKK dan matematika). Instrumen penelitian ini dilakukan untuk mendapatkan data dan informasi yang lengkap untuk memenuhi kajian dalam penelitian.

\section{HASIL DAN PEMBAHASAN PENELITIAN}

Analisis yang digunakan dalam pengujian instumen tes uji coba meliputi analisis validitas, reliabilitas, tingkat kesukaran, dan daya pembeda.

Tabel 2.1 Rekapitulasi Uji Instrumen Tes

\begin{tabular}{|c|c|c|c|c|}
\hline Nomor Butir Soal & Daya Pembeda & Tingkat Kesukaran & Validitas & Reabilitas \\
\hline 1 & Jelek & Mudah & Rendah & \multirow{6}{*}{ Tinggi } \\
\hline 2 & Sangat Baik & Sedang & Sangat Tinggi & \\
\hline 3 & Cukup & Sukar & Tinggi & \\
\hline 4 & Baik & Sedang & Tinggi & \\
\hline 5 & Baik & Sukar & Tinggi & \\
\hline 6 & Cukup & Mudah & Cukup & \\
\hline
\end{tabular}

Berdasarkan hasil uji coba di atas dan setelah berdiskusi dengan pembimbing maka keseluruhan (keenam) soal yang diuji cobakan digunakan sebagai pretest dan posttest.

\section{Deskripsi Kemampuan Berpikir Kreatif Matematis}

Peneliti mendeskripsikan kemampuan berpikir kreatif matematis siswa dan pengolahan dat kedua kelompok siswa yang diteliti yaitu siswa yang memperoleh model pembelajaran Search, Solve, Create and Share (SSCS) dan siswa yang memperoleh model Problem Centered Learning (PCL).

\section{Deskripsi Tes Awal}

Tahap awal yang dilakukan dalam penelitian adalah menyusun instrument tes dan non tes. Instrument tes berupa soal yang memiliki indikator kemmapuan berpikir kreatif matematis. Instruemen tersebut diuji pretest untuk melihat kemampuan awal dari siswa. Uji dilakukan 
dimasing-masing kelas SSCS dan kelas PCL, kemudian data pretest diolah menggunakan SPSS 23.0. Berikut ini Tabel 2.2 adalah hasil data kemampuan awal siswa:

Tabel 2.2. Deskripsi Pretest

\begin{tabular}{|c|c|c|}
\hline Keterangan & SSCS & PCL \\
\hline Sampel Size & 34 & 32 \\
\hline Mean & 21,71 & 19,44 \\
\hline Std. Deviation & 6,36 & 4,81 \\
\hline Skewness & $-0,79$ & 0,12 \\
\hline Kurtosis & 0,173 & $-0,86$ \\
\hline Minimum & 5,00 & 12,00 \\
\hline Maximum & 31,00 & 28,00 \\
\hline
\end{tabular}

Dari hasil deskripsi satistik tes kemampuan awal berpikir kreatif matematis, nilai pada kelas yang memperoleh model pembelajaran SSCS adalah 21,71 dan nilai rata-rata keas yang memperoleh model PCL adalah 19,44 dan artinya kedua kelas tersebut masih memiliki kemampuan berpikir kreatif matematis yang rendah. Untuk mengetahui keadaan kemampuan awal siswa sama atau tidak maka dilakukan uji normalitas, homogenitas, dan uji beda dua ratarata.

Tabel 2.3. Uji Normalitas Data Pretest

\begin{tabular}{|c|c|c|c|}
\hline \multirow{2}{*}{ Kelompok } & \multicolumn{3}{|c|}{ Shapiro-Wilk } \\
\cline { 2 - 4 } & Statistic & Df & Sig. \\
\hline PCL & 0,946 & 32 & 0,111 \\
\hline SSCS & 0,954 & 32 & 0,193 \\
\hline
\end{tabular}

Dari hasil uji normalitas data pre_test pada kedua kelas, dapat di ketahui bahwa nilai signifikan yang di peroleh kedua kelas lebih dari 0,05 yang berarti bahwa kondisi awal kedua kelas sebelum dilakukan treatment berasal dari kelas populasi yang berdistribusi normal.

Tabel 2.4. Uji Homogenitas Data Pretest

\begin{tabular}{|c|c|c|c|}
\hline Levene Statistic & Df $_{1}$ & Df $_{\mathbf{2}}$ & Sig. \\
\hline 2,794 & 1 & 64 & 0,100 \\
\hline
\end{tabular}

Dari hasil uji homogenitas data pre_test dengan menggunakan uji Levene, diperoleh nilai signifikan sebesar 0,100. Berdasarkan kriteria $H_{0}$ tidak ditolak jika nilai sig $>0,05$, maka ditarik kesimpulan bahwa kedua populasi memiliki varians yang homogen.

Tabel 2.5. Uji Beda Dua Rata-Rata Gain Ternormalisasi

\begin{tabular}{|c|c|c|c|c|c|c|c|c|}
\hline \multicolumn{2}{|c|}{ t-test for Equality of Means } \\
\hline & $\mathrm{T}$ & $\mathrm{df}$ & $\begin{array}{c}\text { Sig. } \\
\text { (2-tailed) }\end{array}$ & $\begin{array}{c}\text { Mean } \\
\text { Difference }\end{array}$ & $\begin{array}{c}\text { Std. Error } \\
\text { Difference }\end{array}$ & $\begin{array}{c}95 \% \\
\text { Confidence } \\
\text { Interval of } \\
\text { Difference }\end{array}$ & Ket. \\
\hline $\begin{array}{c}\text { Equal } \\
\text { variances } \\
\text { assume }\end{array}$ & 1,63 & 64 & 0,11 & 2,26838 & 1,39 & $-0,52$ & 5,05 & $\begin{array}{c}\text { H0 tidak } \\
\text { ditolak }\end{array}$ \\
\cline { 2 - 9 }
\end{tabular}


Berdasarkan hasil di atas maka nilai signifikan (2-tailed) adalah 0,11, maka $H_{0}$ tidak ditolak, artinya tidak terdapat perbedaan yang signifikan pada kemampuan awal berpikir kreatif matematis siswa antara kelas yang memperoleh model pembelajaran Search, Solve, Create and Share dan kelas yang memperoleh model Problem Centered Learning.

\section{Deskripsi Tes Akhir (Posttest)}

Setelah diberikan perlakuan maka kedua kelas diuji kembali dan diperoleh hasil analisis data tes akhir sebagai berikut:

Tabel 2.6. Deskripsi Data Posttest

\begin{tabular}{|c|c|c|}
\hline Keterangan & SSCS & PCL \\
\hline Sampel Size & 34 & 32 \\
\hline Mean & 69,15 & 55,29 \\
\hline Std. Deviation & 13,77 & 10,57 \\
\hline Skewness & $-2,68$ & $-0,03$ \\
\hline Kurtosis & 7,17 & $-0,73$ \\
\hline Minimum & 18,00 & 36,00 \\
\hline Maximum & 79,00 & 74,00 \\
\hline
\end{tabular}

Berdasarkan Tabel 2.6, menunjukkan bahwa nilai rata-rata kelas yang memperoleh model pembelajaran Search, Solve, Create and Share lebih baik dibandingkan kelas yang memperoleh model Problem Centered Learning. Dilihat dari standard deviasi, kelas yang memperoleh model pembelajaran Search, Solve, Create and Share sedikit lebih besar yaitu 13,77 dibandingkan dengan kelas yang memperoleh model Problem Centered Learning yaitu sebesar 10,57. Berarti penyebaran skor posttest pada kelas Search, Solve, Create and Share mendekat nilai rata-rata dibandingkan dengan penyebaran skor pretest pada kelas Problem Centered Learning.

\section{Analisis Gain Ternormalisasi Kemampuan Berpikir Kreatif Matematis}

Pada bagian ini peneliti akan menganalisis hasil dari tes kemampuan berpikir kreatif matematis siswa yang memperoleh model pembelajaran Search, Solve, Create and Share dan siswa yang memperoleh model Problem Centered Learning. Analisis gain ternormalisasi dilakukan untuk mengetahui seberapa besar peningkatan kemampuan berpikir kreatif matematis siswa setelah memeperoleh pembelajaran berpikir kreatif dengan model pembelajaran Search, Solve, Create and Share dan model Problem Centered Learning. Hasil dari analisis data gain ternormalisasi adalah sebagai berikut: 
Tabel 2.7. Deskripsi Data Gain Ternormalisasi

\begin{tabular}{|c|c|c|}
\hline Keterangan & SSCS & PCL \\
\hline Sampel Size & 34 & 32 \\
\hline Mean & 21,71 & 19,44 \\
\hline Std. Deviation & 6,36 & 4,81 \\
\hline Skewness & $-0,79$ & 0,12 \\
\hline Kurtosis & 0,173 & $-0,86$ \\
\hline Minimum & 5,00 & 12,00 \\
\hline Maximum & 31,00 & 28,00 \\
\hline
\end{tabular}

Secara rata-rata nilai gain ternormalisasi pada siswa yang memperoleh model pembelajaran Search, Solve, Create and Share adalah 0,84 berada dalam kategori tinggi, dan siswa yang memperoleh model Problem Centered Learning adalah 0,62 berada pada kategori sedang.

\section{Uji Normalitas Gain Ternormalisasi}

Setelah memperoleh data gain ternormalisasi, maka dilakukan uji normalitas nilai gain ternormalisasi dari populasi kedua kelas. Hasil uji normalitas gain ternormalisasi adalah sebagai berikut:

Tabel 2.8. Hasil Uji Normalitas Gain Ternormalisasi

\begin{tabular}{|c|c|c|c|}
\hline \multirow{2}{*}{ Kelompok } & \multicolumn{3}{|c|}{ Shapiro-Wilk } \\
\cline { 2 - 4 } & Statistic & Df & Sig. \\
\hline PCL & 0,968 & 32 & 0,448 \\
\hline SSCS & 0,716 & 32 & 0,000 \\
\hline
\end{tabular}

Dari hasil uji normalitas data gain ternormalisasi pada kedua kelas, dapat diketahui bahwa nilai signifikan dari kelas yang memperoleh model pembelajaran Search, Solve, Create and Share $H_{0}$ ditolak karena sig $=0,000<0,05$, artinya data tidak berasal dari populasi yang berdistribusi normal. Sedangkan kelas yang memperoleh model Problem Centered Learning, $H_{0}$ tidak ditolak karena sig $=0,448>0,05$, artinya data berasal dari populasi yang berdistribusi normal.

\section{Uji Homogenitas Gain Ternormalisasi}

Selanjutnya dilakukan uji homogenitas dain ternormalisasi dari populasi pada data kedua kelompok kelas. Dilakukan untuk melihat kondisi kelas dalam keadaan yang sama. Hasil analisis homogenitas varians populasi data gain ternormalisasi adalah:

Tabel 2.9. Uji Homogenitas Gain Ternormalisasi

\begin{tabular}{|c|c|c|c|c|}
\hline & Levene Statistic & Df $_{1}$ & $\mathbf{D f}_{\mathbf{2}}$ & Sig. \\
\hline Based on Median & 0,235 & 1 & 64 & 0,630 \\
\hline
\end{tabular}


Berdasarkan hasil uji homogenitas, maka dapat dilihat bahwa nilai signifikan gain ternormalisasi menunjukkan sig $=0,630>0,05$, maka $H_{0}$ tidak ditolak, sehingga varians populasi kedua kelas tersebut homogen.

\section{Uji Beda Dua Rata-rata Gain Ternormalisasi}

Uji beda dua rata-rata ini dilakukan untuk mengetahui apakah terdapat perbedaan yang signifikan pada gain ternormalisasi. Setelah dilakukan uji normalitas dan homogenitas maka diperoleh hasil bahwa salah satu kelas tidak berasal dari populasi yang berdistribusi normal dan kedua populasi memiliki varians yang homogen. Oleh karena itu untuk menguji beda dua rata-rata dengan menggunakan uji statistik non parametric Mann-Whitney.

Tabel 2.10. Uji Beda Dua Rata-Rata Gain Ternormalisasi

\begin{tabular}{|l|c|}
\hline & Gain \\
\hline Mann-Whitney $U$ & 154,000 \\
Wilcoxon W & 682,000 \\
Z & $-5,007$ \\
Asymp.Sig. (2-tailed) & 0,0000 \\
\hline
\end{tabular}

Berdasarkan hasil Tabel 2.10, dapat disimpulkan bahwa signifikan (2-tailed) $=0.000<$ 0.05 maka $H_{0}$ ditolak. Artinya, terdapat perbedaan peningkatan kemampuan berpikir kreatif matematis siswa yang memperoleh model pembelajaran Search, Solve, Create and Share dan siswa yang memperoleh model Problem Centered Learning.

\section{Respon Siswa terhadap Pelajaran Matematika}

Menunjukkan bahwa siswa yang memperoleh model pembelajaran Search, Solve, Create and Share dan model Problem Centered Learning berada dalam kategori suka.

\section{KESIMPULAN DAN SARAN}

Kesimpulan yang diperoleh berdasarkan pengelolahan data hasil penelitian dan pembahasan antara lain:

1. Kemampuan awal berpikir kreatif matematis siswa pada kelas yang memperoleh model Search, Solve, Create and Share dan kelas yang memperoleh model Problem Centered Learning adalah tergolong rendah. Sedangkan nilai rata-rata kemampuan akhir siswa yang memperoleh pembelajaran model Search, Solve, Create and Share lebih besar dibandingkan siswa yang memperoleh model Problem Centered Learning.

2. Peningkatan kemampuan berpikir kreatif matematis siswa yang memperoleh model pembelajaran Search, Solve, Create And Share masuk dalam kategori tinggi, sedangkan siswa yang memperoleh model Problem Centered Learning masuk dalam kategori sedang. Itu artinya, peningkatan 
kemampuan berpikir kreatif matematis siswa yang memperoleh model pembelajaran Search, Solve, Create and Share secara signifikan lebih baik daripada siswa yang memperoleh model Problem Centered Learning.

3. Secara keseluruhan respon siswa terhadap kedua model pembelajaran yang telah di terapkan menunjukkan kategori "suka".

Saran yang dapat penulis sampaikan adalah sebagai berikut:

1. Bagi guru kiranya dapat menggunakan model pembelajaran Search, Solve, Create And Share guna meningkatkan keaktifan siswa dalam memecahkan soal-soal yang tidak rutin dan membangun minat belajar siswa.

2. Model Problem Centered Learning dapat digunakan sebagai salah satu alternatif untuk meningkatkan kemampuan berpikir kreatif matematis siswa dan juga digunakan terhadap aspek kemampuan lainnya.

3. Bagi siswa kiranya dapat mengikuti setiap instruksi yang diberikan sehingga dalam proses pembelajaran dapat berlangsung dengan baik dan teratur.

4. Kiranya hasil penelitian ini dapat dijadikan bahan referensi bagi para peneliti-peneliti lainya secara bijak.

\section{DAFTAR PUSTAKA}

Edistria, E. (2012). Pengaruh Penerapan Hypnoeaching Dalam ProblemBased Learning Terhadap Kemampuan Komunikasi Dan Berpikir Kreatif Matematis Siswa Sekolah Menengah Pertama. Tesis. Universitas Pendidikan Indonesia. Bandung

Hamzah, S. (2015). Pengaruh Pembelajaran Berpusat Masalah (Problem Centered Learning) terhadap Kemampuan Koneksi Matematika Siswa Kelas VIII. Jurnal. UNG: (hal 3-4)

Hikmah, N. (2015). Pengaruh Penggunaan Model Pembelajaran Dan Konsep Diri Terhadap Kemampuan Berpikir Kreatif Matematis. Jurnal Formatif 3(3): 236-249

Irwan. (2011). Pengaruh Pendekatan Problem Posing Model Search, Solve, Create And Share Dalam Upaya Meningkatkan Kemampuan Penalaran Matematis. Jurnal Penelitian Pendidikan Vol.12 No.1

Kurniawan. (2016). Pengaruh Model Pembelajaran Problem Centered Learning Terhadap Kemampuan Pemecahan Masalah Matematika Siswa SMK.

Lestari. (2018). Peningkatan Daya Kreativitas Dalam Pembelajaran Seni Budaya Dan Keterampilan Melalui Media Grafis Dengan Memanfaatkan Bahan Daur Ulang Pada Siswa Kelas V SD Negeri Pengkok I Sragen Tahun Pelajaran 2015/2016. Jurnal Mahasiswa Unisri Vol 1, No 2

Munandar, U. (2009). Pengembangan Kreativitas Anak Berbakat. Jakarta: PT.Rineka Cipta.

Nirmala, E. (2016). Pengunaan Model Team Product dalam Pembelajaran Matematika Terhadap Kemampuan Berpikir Kreatif Matematis Siswa SMK. Skripsi.Universitas Pasundan. Bandung

Nurjannah, D. (2017). Pengaruh Model Pembelajaran Search, Solve, Create, And Share (SSCS) Terhadap Kemampuan Representasi Visual Matematis Dan Habits Of Mind Siswa SMP. Skripsi. FKIP Unpas. 
Prawindaswari, P. D, dkk. (2015). Pengaruh Model Pembelajaran Search, Solve, Create,And Share (SSCS) Terhadap Hasil Belajar IPA Siswa Kelas IV Sekolah Dasar. E-jurnal PGSD universitas Ganesha. Vol: 3 No.1

Rachmawati, Y dan Kurniati, E. (2003). Strategi Pengembangan Kreativitas Pada Anak Usia Taman Kanak-Kanak. Jakarta: DEPDIKNAS

Rahmi. (2011). Metode Pemecahan Masalah Model SSCS (Search, Solve, Create, And Share) Dalam Pembelajaran Matematika. Percikan. Vol 120. ISSN 0854-8986.

Susanto, H. M. (2016). Kemampuan Berpikir Kreatif Matematis Dan Disposisi Matematis Dalam Pembelajaran Dengan Pendekatan Ang's Framework For Mathematical Modelling Instruction. Skripsi. UPI

Susilo, T. A. (2015). Pengaruh Sikap Siswa Pada Matematika Terhadap Hasil Belajar Matematika Di SMP. Jurnal Pendidikan Matematika STKIP PGRI Sidoarjo. Vol 3, No.1.

Utami, R. P. (2011). Pengaruh Model Pembelajaran Search, Solve, Create And Share Dan Problem Based Learning Terhadap Prestasi Belajar Dan Kreativitas Siswa. Jurnal Bioedukasi. Vol 4, No 2. Hlm 57-71

Wijayanti, D. (2010). Perbedaan Kreativitas Antara Anak Pendidikan Formal Dengan Anak Homeschooling. Jurnal Spirits. Vol 1, No.1. Hlm 1-11 